\title{
The effect of stromal cell-derived factor 1 (SDF1/CXCL12) genetic polymorphism on HIV-1 disease progression
}

\author{
EDNA MARIA VISSOCI REICHE ${ }^{1}$, MARIA ANGELICA EHARA WATANABE ${ }^{2}$, ANA MARIA BONAMETTI ${ }^{1}$, \\ HELENA KAMINAMI MORIMOTO ${ }^{1}$, ARILSON AKIRA MORIMOTO ${ }^{1,3}$, SUSANA LILIAN WIECHMANN ${ }^{1}$, \\ JOSE WANDER BREGANÓ ${ }^{1}$, TIEMI MATSUO ${ }^{4}$, FERNANDO VISSOCI REICHE ${ }^{1}$, HELEN CRISTINA MIRANDA $^{2}$, \\ KAREN BRAJÃO OLIVEIRA ${ }^{2}$, INGRIDT HILDEGARD VOGLER ${ }^{1}$ and ALEXANDRA REGINA SISCAR ${ }^{1}$ \\ ${ }^{1}$ Health Sciences Center, University Hospital of Londrina State University; ${ }^{2}$ Biological Sciences Center, \\ Londrina State University; ${ }^{3}$ Integrated Center of Infectious Diseases, Health State Secretary of the State; \\ ${ }^{4}$ Exacts Sciences Center, Londrina State University, Londrina, Paraná, Brazil
}

Received March 24, 2006; Accepted June 19, 2006

\begin{abstract}
The human immunodeficiency virus type 1 (HIV-1) epidemic is increasing in Brazil, and little information has been reported about the genetic host factors related to HIV-1 infection in the Brazilian population. A polymorphism in the conserved 3' untranslated region of the stromal cell-derived factor 1 (SDF1/CXCL12) gene has been related either to resistance to HIV-1 infection and delayed progression to AIDS or to rapid disease progression and death. A longitudinal study was conducted to evaluate the association of the SDF1 polymorphism and the progression of HIV-1 infection in 161 asymptomatic patients infected with HIV-1 (ASYMPT) and 617 patients with AIDS (SYMPT) from Londrina and the surrounding region, southern Brazil. The endpoints used were the development of AIDS, death, and the slopes of the CD4+ T cell counts and HIV-1 RNA plasma levels. Among the 161 ASYMPT patients, all of the 7 patients (4.3\%) homozygous for the mutation remained asymptomatic $(\mathrm{p}=0.1906) ; 6$ of them had not initiated antiretroviral therapy. Among the 617 patients with AIDS, 40 (6.5\%) progressed to death. Of these, 33/388 (8.5\%) did not have the SDF1-3'A allele, 6/196 (3.1\%) were heterozygous and 1/33 (3.0\%) was homozygous for the SDF13 'A allele $(\mathrm{p}=0.029)$. The SDF1 genotypes were not associated with the surrogate markers of HIV-1 disease progression such as the $\mathrm{CD}^{+}{ }^{+} \mathrm{T}$ cell decline and plasma HIV-1 RNA levels. The results observed in this study support the hypothesis that the
\end{abstract}

Correspondence to: Dr Edna Maria Vissoci Reiche, Health Sciences Center, Department of Pathology, Clinical Analysis and Toxicology, University Hospital of Londrina State University, Av. Robert Koch, 60, Vila Operária, CEP 86.038-440, Londrina, Paraná, Brazil

E-mail: reiche@sercomtel.com.br

Key words: genetic polymorphism, stromal cell-derived factor 1 (SDF1/CXCL12), human immunodeficiency virus type 1, acquired immunodeficiency syndrome, chemokines mutation of SDF1-3'A could have a possible late-stage protective effect on HIV-1 disease progression in the Brazilian population.

\section{Introduction}

Different rates of disease progression are observed in individuals infected with the human immunodeficiency virus type 1 (HIV-1) (1), and the discovery that certain chemokine receptors are utilized by different strains of HIV-1 as cofactors to gain entry into cells has greatly expanded the number of candidate host factors that may influence the pathogenesis of HIV-1 infection (2-9). A polymorphism in conserved sequences of the $3^{\prime}$ untranslated region of the gene encoding the $\mathrm{CXC}$ chemokine stromal cell-derived factor 1 (SDF1/CXCL12), named SDF1-3'A, the single natural ligand of the HIV-1 coreceptor CXCR4, has been described. Individuals homozygous for the SDF1-3'A variant have shown a remarkable level of protection against AIDS, supporting the hypothesis that the SDF1-3'A variant restricts the emergence of X4 tropic HIV-1 strains, with overproduction of SDF1/CXCL12 in local compartments (10). SDF1/CXCL12 then binds to and blocks the CXCR4 receptors required for $\mathrm{X} 4$ viruses to emerge and predominate (10). However, the disease-retarding role of homozygosity for the SDF1-3'A allele has not been confirmed in other studies (11-20).

The frequency of SDF1/CXCL12 genotypes and SDF1-3'A allele vary significantly among different populations, ranging from 0.029 in Africans to 0.7145 in Oceanian populations $(21,22)$. Among Brazilian individuals the SDF1-3'A allelic frequencies ranged from 0.1818 to 0.2161 (23). Although the HIV-1 epidemic is increasing in Brazil, where over 300,000 cases of HIV/AIDS were documented from 1980 to 2003 (24), little information about the effect of the host genetic mutations on the clinical course of HIV-1 infection has been reported for the Brazilian population. To address this question, a longitudinal study was carried out to determine the effect of SDF1/CXCL12 polymorphism on the progression of HIV-1 infection in asymptomatic and symptomatic patients infected with HIV-1 from southern Brazil. 
Table I. Demographic, immunological, and virological characteristics, and the SDF1/CXCL12 genetic polymorphism of the HIV-1 infected ASYMPT and SYMPT patients enrolled during the period from September 2001 to December 2003 and followed-up until June 2004, without considering the use of ARV.

\begin{tabular}{|c|c|c|c|c|c|c|c|c|}
\hline \multirow[t]{2}{*}{ Group } & \multirow[t]{2}{*}{$\begin{array}{c}\text { Sex } \\
(\% \text { male })\end{array}$} & \multirow{2}{*}{$\begin{array}{c}\text { Age } \\
\text { range } \\
\text { (median) } \\
\text { years }^{\mathrm{a}}\end{array}$} & \multirow[t]{2}{*}{$\begin{array}{c}\mathrm{CD}^{+} \mathrm{T} \text { cell } / \mathrm{mm}^{3} \\
\text { range } \\
(\text { median })^{\mathrm{a}}\end{array}$} & \multirow[t]{2}{*}{$\begin{array}{c}\mathrm{CD}^{+} \mathrm{T} \text { cell } / \mathrm{mm}^{3} \\
\text { range } \\
(\text { median })^{\mathrm{a}}\end{array}$} & \multirow[t]{2}{*}{$\begin{array}{l}\text { HIV-1 RNA copies } / \mathrm{ml} \\
\text { range } \\
{\text { (median })^{\mathrm{a}}}^{\text {mat }}\end{array}$} & \multicolumn{3}{|c|}{$\begin{array}{l}\text { SDF1/CXCL12 genotype } \\
\text { frequency } \\
\text { n }(\%)\end{array}$} \\
\hline & & & & & & wt/wt & $3^{\prime} \mathrm{A} / \mathrm{wt}$ & $3^{\prime} \mathrm{A} / 3^{\prime} \mathrm{A}$ \\
\hline $\begin{array}{l}\text { ASYMPT }^{c} \\
(n=161)\end{array}$ & $87(54.0)$ & $\begin{array}{c}14.7-70.4 \\
(32.3)\end{array}$ & $\begin{array}{l}355-1542 \\
(534)\end{array}$ & $\begin{array}{c}326-2259 \\
(932)\end{array}$ & $\begin{array}{c}<400-610,000 \\
(5,420)\end{array}$ & $110(68.3)$ & $44(27.3)$ & $7(4.3)$ \\
\hline $\begin{array}{l}\text { SYMPT }^{d} \\
(n=617)\end{array}$ & $346(56.1)$ & $\begin{array}{c}15.1-79.5 \\
(36.5)\end{array}$ & $\begin{array}{c}1-1240 \\
(281)\end{array}$ & $\begin{array}{c}15-3795 \\
(811)\end{array}$ & $\begin{array}{c}<400->750,000 \\
(1,980)\end{array}$ & 388 (62.9) & $196(31.8)$ & $33(5.3)$ \\
\hline
\end{tabular}

${ }^{a}$ Baseline values obtained after enrollment in the study. ${ }^{\mathrm{b}} \mathrm{wt} / \mathrm{wt}$, wild-type/wild-type genotype; 3'A/wt, heterozygous mutation; 3'/A/3'A, homozygous mutation. ${ }^{\mathrm{c} H I V}$-1-infected asymptomatic patients and with $\mathrm{CD}^{+}{ }^{+} \mathrm{T}$ cell counts $\geq 350 \mathrm{cells} / \mathrm{mm}^{3}$; caucasians $(\mathrm{n}=106 / 65.8 \%)$; non-caucasian $(\mathrm{n}=55 / 29.5 \%)$. ${ }^{\mathrm{d}} \mathrm{HIV}$ 1 infected patients with the symptoms of the disease and/or CD $4^{+} \mathrm{T}$ cell counts $<350$ cells $/ \mathrm{mm}^{3}$; caucasian $(\mathrm{n}=435 / 70.5 \%)$; non-caucasian $(\mathrm{n}=182 / 29.5 \%)$. $\mathrm{n}$, number of samples assayed; \%, percentage.

\section{Material and methods}

The protocol was approved by the Institutional Research Ethics committees of Londrina State University and of the Health State Secretary of the State of Paraná. The individuals were invited to participate and informed in detail about the research, and voluntary written consent was obtained from them.

Study subjects. A total of 778 patients infected with HIV-1 attending various specialized, public, and nonprofit centers of sexually transmitted diseases from Londrina and region, Paraná State, southern Brazil, were enrolled from October 2001 to December 2003 and followed until June 2004. The patients were divided into two groups: The first group consisted of 161 seroprevalent asymptomatic patients infected with HIV-1 with CD4 ${ }^{+} \mathrm{T}$ cell counts $\geq 350$ cells $/ \mathrm{mm}^{3}$ (ASYMPT). At the time of enrollment, 102 subjects were not receiving antiretroviral therapy (ARV), and 59 were on ARV. During the follow-up period $(n=157), 89$ subjects did not receive ARV, and 68 received ARV. The second group consisted of 617 seroprevalent outpatients and inpatients infected with HIV-1 with the symptoms of the disease and/or $\mathrm{CD}^{+} \mathrm{T}$ cell counts $<350$ cells $/ \mathrm{mm}^{3}$ (SYMPT), according to the Brazilian criteria that considers a CD4 ${ }^{+} \mathrm{T}$ cell count of $350 / \mathrm{mm}^{3}$ as the cut-off value and/or the presence of opportunist infections for defining and diagnosing the disease (25). At the time of enrollment ( $n=617), 128$ subjects were not receiving ARV, and 489 received ARV. During the follow-up period ( $\mathrm{n}=611), 45$ subjects did not receive ARV, and 566 received ARV.

Immunologic and virologic assays. Screening tests by enzyme immunosorbent assay (ELISA, Murex ${ }^{\mathrm{TM}}$ HIV-1.2.0, Murex Biotech Limited, Dartford Kent, England, UK), microparticle enzyme-immunoassay (MEIA, Abbott Axsym ${ }^{\mathrm{TM}}$ System, HIV-1/2 gO, Abbott GmbH, Wiesbaden, Delkenheim, Germany), confirmatory tests of indirect immunofluorescence (slides from Fiocruz Institute, Rio de Janeiro, Brazil) and Western blot to anti-HIV-1 (Genelabs Diagnostics, Singapore) were performed in serum samples according to standard governmental procedures (26). Baseline and follow-up CD4+ and $\mathrm{CD} 8^{+} \mathrm{T}$ cell counts were evaluated by flow cytofluorometry (FACSCount $^{\mathrm{TM}}$, Becton-Dickinson and Company, San Jose, CA, USA), and the results were recorded as number of cells $/ \mathrm{mm}^{3}$.

The baseline and follow-up plasma HIV-1 RNA levels were obtained using the COBAS AMPLICOR ${ }^{\mathrm{TM}}$ MONITOR HIV-1 version 1.5 (Roche Diagnostic Systems, Brachburg, NJ, USA), with a lower limit of detection of 400 copies $/ \mathrm{ml}$ and a linear dynamic range of up to 750,000 copies $/ \mathrm{ml}$. The viral load was recorded as the number of HIV-1 RNA copies/ml and was $\log _{10}$ copies/ml transformed.

The following endpoints were considered for analysis: the development of AIDS, according to the Brazilian criteria for the definition of the disease (25), death, and the slopes of the $\mathrm{CD}^{+}{ }^{+} \mathrm{T}$ cell counts and plasma HIV-1 RNA levels.

SDF1/CXCL12 genetic polymorphism. Genomic DNA was extracted from cryopreserved peripheral blood cells using GFX Genomic Blood Purification ${ }^{\mathrm{TM}}$ (Amersham Biosciences, Piscataway, NJ, USA), and 100-200 ng of DNA were analyzed by polymerase chain reaction (PCR) and restriction fragment length polymorphism (RFLP), as described elsewhere $(10,23)$.

Statistical analysis. All data were recorded with the Epi Info software v.6.04d (27). The median, mean and percentage were used to describe the results. The proportions of different genotypes between groups were analyzed by the $\chi^{2}$ test. The slopes of the $\mathrm{CD}^{+} \mathrm{T}$ cell counts and plasma HIV-1 RNA levels were obtained with the Excel program. Data were analyzed statistically by the Kruskal-Wallis test and ANOVA using the Epi Info v.6.04d (27) and SAS Institute (28) software. $\mathrm{P}$-values $<0.05$ were considered statistically significant.

\section{Results}

The demographic, immunological, and virological status, without considering the use of ARV, and the SDF1/CXCL12 genetic polymorphism of the 161 ASYMPT and 617 SYMPT 

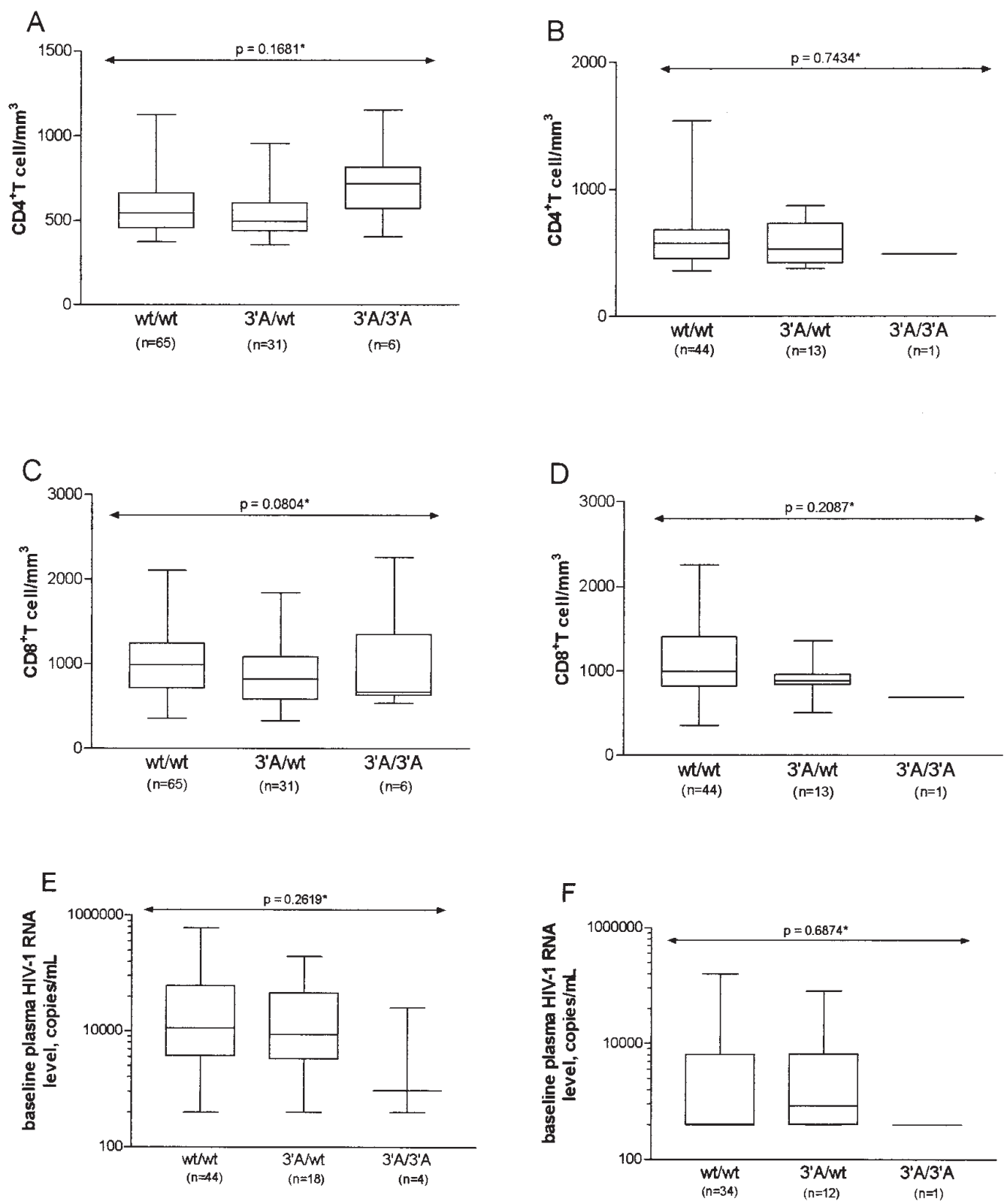

Figure 1. Box-Whisker-Plot (interquartile range, median, 10th and 90th percentiles) of the CD4+ $\mathrm{T}$ cell counts of patients without (A) and with (B) ARV; of $\mathrm{CD}^{+} \mathrm{T}$ cell counts of patients without (C) and with (D) ARV, and viral load of patients without (E) and with (F) ARV. The results were obtained in the first peripheral blood sample after inclusion of the ASYMPT HIV-1-infected patients, according to the SDF1/CXCL12 genotype. wt/wt, wild-type/wild-type; 3'A/wt, heterozygous mutation; 3'A/3'A, homozygous mutation. "Kruskal-Wallis test. $\mathrm{n}=$ number of samples. Boxes represent interquartile ranges; the horizontal bar within each box indicates the median. Whiskers indicate the 10th and 90th percentiles.

patients are shown in Table I. Among the ASYMPT patients, the distribution of the SDF1/CXCL12 genotypes was SDF1 wt/wt in 110 patients $(68.3 \%), \mathrm{SDF} 1-3 \mathrm{~A} / \mathrm{wt}$ in 44 patients $(27.3 \%)$ and SDF1-3'A/3'A in 7 patients $(4.3 \%)$ and the allelic frequency was 0.1800 (95\% CI: 0.1406-0.2275). Among the 617 SYMPT patients, the distribution of the SDF1 genotypes was SDF1 wt/wt in 388 patients $(62.9 \%)$, SDF1-3'A/wt in 196 patients $(31.8 \%)$ and SDF1-3'A/3'A in 33 patients $(5.3 \%)$ and the allelic frequency was 0.2123 (95\% CI: $0.1900-0.2364)$.

SDF1/CXCL12 genetic polymorphism, baseline $\mathrm{CD}^{+}$and $C D 8^{+} T$ cell counts and plasma HIV-1 RNA levels. The median and interquartile range (IQR) of $\mathrm{CD}^{+}$and $\mathrm{CD}^{+} \mathrm{T}$ cell counts and the plasma HIV-1 RNA levels observed in the
ASYMPT patients without and with ARV according to SDF1/CXCL12 genotype are shown in Fig. 1. The baseline $\mathrm{CD}^{+}$and $\mathrm{CD}^{+} \mathrm{T}$ cell counts and viral load of ASYMPT patients did not differ with respect to SDF1/CXCL12 genotype among the patients who had not initiated ARV and among those who had initiated ARV. Among the ASYMPT patients with the wt/wt, 3'A/wt and 3'A/3'A genotypes who had not initiated ARV, median CD4 ${ }^{+} \mathrm{T}$ cell counts were 543 cells $/ \mathrm{mm}^{3}$ (range 376-1126, IQR 456-663), 497 cells $/ \mathrm{mm}^{3}$, (range 355-954, IQR 436-605) and 717 cells $/ \mathrm{mm}^{3}$ (range 4041156, IQR 569-818), respectively $(\mathrm{p}=0.1681)$. Among the ASYMPT patients with the wt/wt, 3'A/wt, and 3'A/3'A genotypes who had initiated ARV, the median $\mathrm{CD}^{+}{ }^{+} \mathrm{T}$ cell counts were 575 cells $/ \mathrm{mm}^{3}$ (range 358-1542, IQR 449-683), 

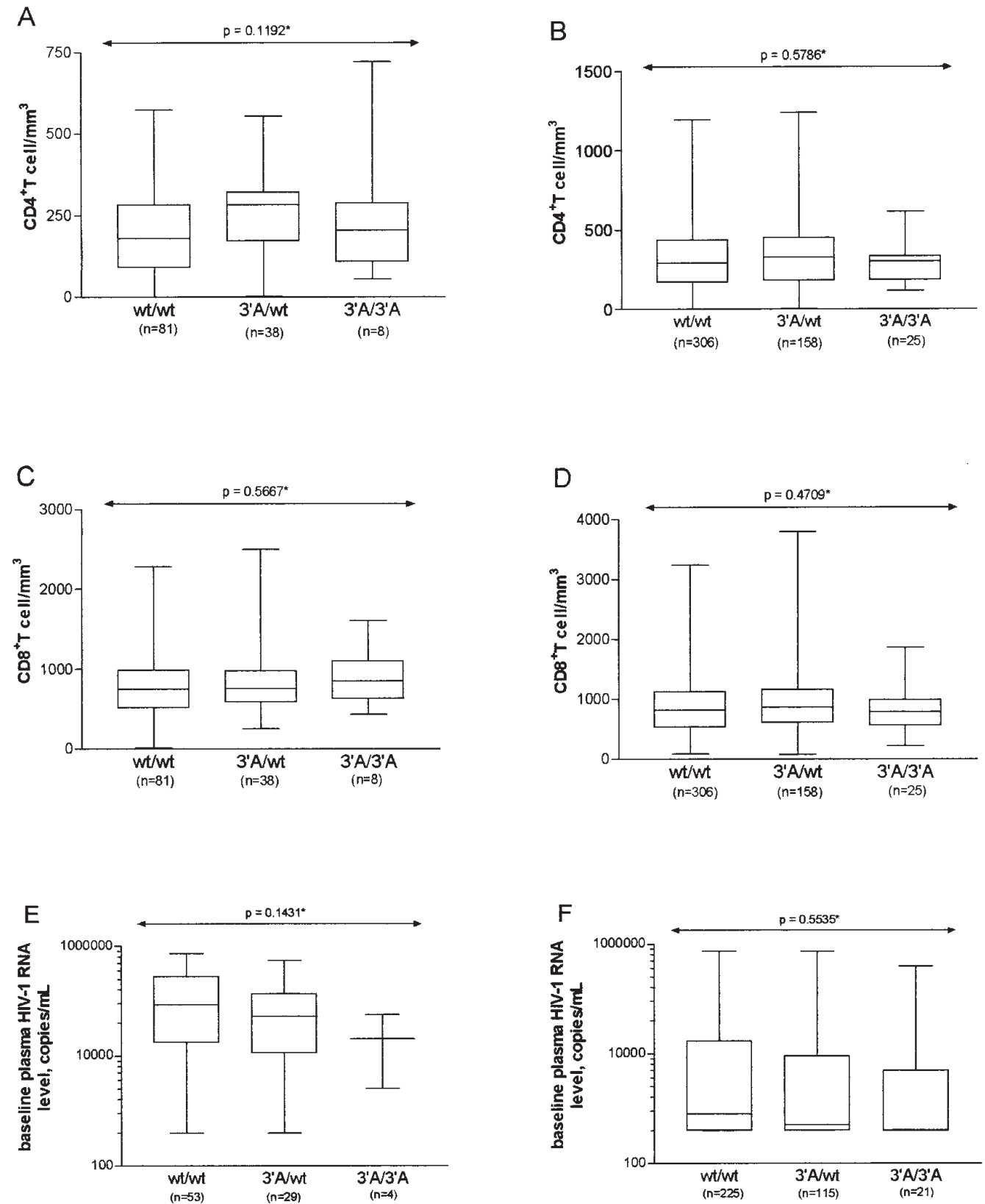

Figure 2. Box-Whisker-Plot (interquartile range, median, 10th and 90th percentiles) of CD4 $4^{+} \mathrm{T}$ cell counts of patients without (A) and with (B) ARV; of CD8 ${ }^{+}$ T cell counts of patients without (C) and with (D) ARV, and viral load of patients without (E) and with (F) ARV. The results were obtained in the first peripheral blood sample after inclusion of SYMPT HIV-1-infected patients, according to the SDF1/CXCL12 genotype. wt/wt, wild-type/wild-type; 3'A/wt, heterozygous mutation; 3'A/3'A, homozygous mutation. "Kruskal-Wallis test. $\mathrm{n}=$ number of samples. Boxes represent interquartile ranges; the horizontal bar within each box indicates the median. Whiskers indicate the 10th and 90th percentiles.

529 cells $/ \mathrm{mm}^{3}$ (range 378-874, IQR 419-734) and 494 cells $/ \mathrm{mm}^{3}$, respectively $(\mathrm{p}=0.7434)$. Regarding $\mathrm{CD}^{+} \mathrm{T}$ cell counts, in the ASYMPT patients with the wt/wt, $3^{\prime} \mathrm{A} / \mathrm{wt}$, and 3'A/3'A genotypes who had not initiated ARV, the medians were 985 cells $/ \mathrm{mm}^{3}$ (range 358-2109, IQR 713-1249), 821 cells $/ \mathrm{mm}^{3}$, (range 326-1843, IQR 575-1087) and 671 cells $/ \mathrm{mm}^{3}$ (range 534-2259, IQR 628-1355), respectively $(\mathrm{p}=0.1681)$. Among the ASYMPT patients with the wt/wt, $3^{\prime} \mathrm{A} / \mathrm{wt}$, and $31 \mathrm{~A} / 3^{\prime} \mathrm{A}$ genotypes who had initiated ARV, the medians were 994 cells $/ \mathrm{mm}^{3}$ (range 351-2256, IQR 8141409), 884 cells $/ \mathrm{mm}^{3}$ (range 507-1359, IQR 832-959), and 687 cells $/ \mathrm{mm}^{3}$, respectively $(\mathrm{p}=0.7434)$. The baseline viral load was obtained for 108 of the ASYMPT patients. The values observed in the patients with the SDF1-wt/wt genotype who had not initiated ARV (median 11,200 copies/ml; range $<400-610,000$, IQR 3710-60,950) and who had initiated ARV (median $<400$ copies/ml, range $<400-160,000$, IQR $<400-6,550)$ were higher than those observed in the patients with the SDF1-3'A/3'A genotype who had not initiated ARV (median 938 copies/ml, range <400-25,400) and who had initiated ARV (median $<400$ copies $/ \mathrm{ml}$ ). However, these differences were not statistically significant ( $\mathrm{p}=0.2619$ and 0.6874 , respectively).

In the group of SYMPT patients, the baseline $\mathrm{CD}^{+}$and $\mathrm{CD}^{+} \mathrm{T}$ cells counts and viral load (Fig. 2) did not differ with respect to SDF1/CXCL12 genotypes among the patients who 
Table II. Clinical course of the 161 HIV-1-infected ASYMPT patients enrolled during the period from September 2001 to December 2003, with follow-up until June 2004, in Londrina and the surrounding region, Paraná, Brazil, according to SDF1/CXCL12 genotype.

\begin{tabular}{|c|c|c|c|c|}
\hline \multirow[b]{2}{*}{ Parameters } & \multicolumn{3}{|c|}{ SDF1/CXCL12 genotypes ${ }^{a}$} & \multirow{2}{*}{$\begin{array}{l}\text { Total } \\
\text { n (\%) }\end{array}$} \\
\hline & $\mathrm{wt} / \mathrm{wt}$ & 3'A/wt & $3^{\prime} \mathrm{A} / 3^{\prime} \mathrm{A}$ & \\
\hline \multicolumn{5}{|c|}{ First anti-HIV-1 positive test (months) ${ }^{b}$} \\
\hline Range & $6.2-180$ & $14.7-181.4$ & $28.3-185$ & \\
\hline Median & 55.7 & 53.9 & 68.3 & \\
\hline Mean $( \pm S D)$ & $60.9( \pm 33.9)$ & $60.4( \pm 36.5)$ & $75.5( \pm 56.5)$ & \\
\hline \multicolumn{5}{|c|}{ Clinical evolution ${ }^{\mathrm{c}} \mathrm{n}(\%)$} \\
\hline Asymptomatic & $79(71.8)$ & $29(65.9)$ & $7(100.0)$ & $115(71.4)$ \\
\hline $\operatorname{AIDS}^{\mathrm{d}}$ & $28(25.4)$ & $14(31.8)$ & $0(0)$ & $42(26.1)$ \\
\hline Without follow-up & $3(2.7)$ & $1(2.3)$ & $0(0)$ & $4(2.5)$ \\
\hline Total & $110(68.3)$ & $44(27.3)$ & $7(4.3)$ & $161(100.0)$ \\
\hline
\end{tabular}

${ }^{\mathrm{a}} \mathrm{wt} / \mathrm{wt}$, wild-type/wild-type genotype; 3'A/wt, heterozygous mutation; 3'/A/3'A, homozygous mutation. ${ }^{\mathrm{b} K r u s k a l-W a l l i s ~ t e s t, ~} \chi^{2}: 0.3056$, degree of freedom 2 , $\mathrm{p}=0.8583 .{ }^{\mathrm{c}}$ Chi-square test, $\chi^{2}: 3.3150$, degree of freedom 2, $\mathrm{p}=0.1906 .{ }^{\mathrm{d}}$ According to the Brazilian AIDS case definition (Brasil, 1998b). $n, n u m b e r$ of patients; \%, percentage; SD, standard deviation.

Table III. Clinical course of the 617 HIV-1-infected SYMPT patients enrolled during the period from September 2001 to December 2003, with follow-up until June 2004, in Londrina and the surrounding region, Paraná, Brazil, according to SDF1/CXCL12 genotype.

\begin{tabular}{|c|c|c|c|c|}
\hline \multirow[b]{2}{*}{ Parameters } & \multicolumn{3}{|c|}{ SDF1/CXCL12 genotypes ${ }^{a}$} & \multirow{2}{*}{$\begin{array}{l}\text { Total } \\
\mathrm{n}(\%)\end{array}$} \\
\hline & $\mathrm{wt} / \mathrm{wt}$ & $3^{\prime} \mathrm{A} / \mathrm{wt}$ & $3^{\prime} \mathrm{A} / 3^{\prime} \mathrm{A}$ & \\
\hline \multicolumn{5}{|c|}{ First anti-HIV-1 positive test (months) ${ }^{\mathrm{b}}$} \\
\hline Range & $3.1-216$ & $4.7-204$ & $19.9-228$ & \\
\hline Median & 66.6 & 64.0 & 64.5 & \\
\hline Mean $( \pm$ SD $)$ & $74.8( \pm 41.3)$ & $71.4( \pm 37.7)$ & $68.7( \pm 40.6)$ & \\
\hline \multicolumn{5}{|c|}{ Clinical evolution ${ }^{\mathrm{c}} \mathrm{n}(\%)$} \\
\hline $\mathrm{AIDS}^{\mathrm{d}}$ & $351(90.5)$ & $188(95.5)$ & $32(96.9)$ & $571(92.5)$ \\
\hline Death & $33(8.5)$ & $6(3.1)$ & $1(3.0)$ & $40(6.5)$ \\
\hline Without follow-up & $4(1.0)$ & $2(1.0)$ & $0(0)$ & $6(1.0)$ \\
\hline Total & $388(62.9)$ & $196(31.8)$ & $33(5.3)$ & $17(100.0)$ \\
\hline
\end{tabular}

${ }^{\mathrm{a}} \mathrm{wt} / \mathrm{wt}$, wild-type/wild-type genotype; 3'A/wt, heterozygous mutation; 3'/A/3'A, homozygous mutation. ${ }^{\mathrm{b}} \mathrm{Kruskal-Wallis} \mathrm{test,} \chi^{2}$ : 1.1675, degree of freedom 2, $\mathrm{p}=0.5578$. ${ }^{\mathrm{c}}$ Chi-square test $\chi^{2}: 7.0799$, degree of freedom 2, $\mathrm{p}=0.0290$. ${ }^{\mathrm{d}}$ According to the Brazilian AIDS case definition (Brasil, 1998b). $\mathrm{n}$, number of patients; \%, percentage; SD, standard deviation

had not initiated ARV as well as among the patients who had initiated ARV. Regarding CD4+ $\mathrm{T}$ cells, among the patients with the wt/wt, 3'A/wt and 3'A/3'A genotypes who had not initiated ARV, the medians were 181 cells $/ \mathrm{mm}^{3}$ (range 1-575, IQR 90-284), 283 cells $/ \mathrm{mm}^{3}$, (range 2-556, IQR 171-322) and 205 cells $/ \mathrm{mm}^{3}$ (range 56-722, IQR 109-288), respectively $(\mathrm{p}=0.1192)$. Among the patients with the wt/wt, 3'A/wt and 3'A/3'A genotypes who had initiated ARV, the median $\mathrm{CD}^{+} \mathrm{T}$ cell counts were 293 cells $/ \mathrm{mm}^{3}$ (range $1-1195$, IQR 167-437), 326 cells $/ \mathrm{mm}^{3}$ (range 4-1240, IQR 181-453) and 304 cells $/ \mathrm{mm}^{3}$ (range 119-615, IQR 184-337), respectively $(\mathrm{p}=0.5786)$. Among the patients with the wt/wt, $3^{\prime} \mathrm{A} / \mathrm{wt}$ and 3'A/3'A genotypes who had not initiated ARV, the median $\mathrm{CD}^{+} \mathrm{T}$ cell counts were 753 cells $/ \mathrm{mm}^{3}$ (range $15-2284, \mathrm{IQR}$ 517-1000), 758 cells $/ \mathrm{mm}^{3}$, (range 257-2501, IQR 579-1006) and 849 cells $/ \mathrm{mm}^{3}$ (range 432-1606, IQR 627-1104), respectively $(\mathrm{p}=0.5667)$. Among the patients with the $\mathrm{wt} / \mathrm{wt}$, 3'A/wt and 3'A/3'A genotypes who had initiated ARV, the medians were 819 cells $/ \mathrm{mm}^{3}$ (range 92-3242, IQR 530-1129), 867 cells $/ \mathrm{mm}^{3}$ (range 78-3795, IQR 596-1153) and 793 cells/ $\mathrm{mm}^{3}$ (range 222-1862, IQR 555-1129), respectively $(p=0.4709)$. The baseline viral load was obtained for 437 
Table IV. Slope of the plasma levels of $\mathrm{CD}^{+}{ }^{+} \mathrm{T}$ cells and HIV-1 RNA from HIV-1-infected ASYMPT patients (Group 1) and from patients with AIDS (Group 2), considering the ARV therapy and the SDF1/CXCL12 genetic polymorphism, followed-up from September 2001 to June 2004, in Londrina and the surrounding region, Paraná, southern Brazil.

\begin{tabular}{|c|c|c|c|c|c|c|c|}
\hline \multirow[t]{2}{*}{ Group $^{\mathrm{a}}$} & \multirow[b]{2}{*}{ SDF1 genotype ${ }^{b}$} & \multirow[b]{2}{*}{ ARV } & \multicolumn{2}{|c|}{$\mathrm{CD} 4^{+} \mathrm{T}$} & \multicolumn{3}{|c|}{ HIV-1 RNA plasma level/year } \\
\hline & & & $\mathrm{n}$ & $\begin{array}{c}\text { cells } \mathrm{mm}^{3} / \text { year }^{\mathrm{c}} \\
( \pm \mathrm{SD})\end{array}$ & $\mathrm{n}$ & $\begin{array}{l}\text { copies } / \mathrm{ml}^{\mathrm{d}} \\
( \pm \mathrm{SD})\end{array}$ & $\begin{array}{c}\log _{10} \text { copies } / \mathrm{ml}^{\mathrm{e}} \\
( \pm \mathrm{SD})\end{array}$ \\
\hline \multirow{6}{*}{1} & $\mathrm{wt} / \mathrm{wt}$ & No & 50 & $-56( \pm 434)$ & 36 & $-21.048( \pm 112.799)$ & $-0,223( \pm 1,069)$ \\
\hline & $\mathrm{wt} / \mathrm{wt}$ & Yes & 41 & $-38( \pm 323)$ & 38 & $-2.828( \pm 26.692)$ & $-0,113( \pm 0,858)$ \\
\hline & $3^{\prime} \mathrm{A} / \mathrm{wt}$ & No & 24 & $-69( \pm 505)$ & 19 & $-23.386( \pm 52.229)$ & $-0,679( \pm 1,612)$ \\
\hline & $3^{\prime} \mathrm{A} / \mathrm{wt}$ & Yes & 13 & $-28( \pm 148)$ & 13 & $+7.246( \pm 29.941)$ & $+0,073( \pm 0,412)$ \\
\hline & $3^{\prime} \mathrm{A} / 3^{\prime} \mathrm{A}$ & No & 04 & $-88( \pm 247)$ & 03 & $-182( \pm 260)$ & $-0,047( \pm 0,04)$ \\
\hline & $3^{\prime} \mathrm{A} / 3^{\prime} \mathrm{A}$ & Yes & 01 & $0(0)$ & 01 & $0(0)$ & $0(0)$ \\
\hline \multirow{6}{*}{2} & $\mathrm{wt} / \mathrm{wt}$ & No & 78 & $+133( \pm 275)$ & 64 & $-53.201( \pm 289.869)$ & $-0,623( \pm 1,468)$ \\
\hline & $w t / w t$ & Yes & 284 & $+21( \pm 217)$ & 268 & $+3.150( \pm 141.981)$ & $-0,072( \pm 0,774)$ \\
\hline & $3^{\prime} \mathrm{A} / \mathrm{wt}$ & No & 31 & $-48( \pm 350)$ & 27 & $-65.243( \pm 134.734)$ & $-0,574( \pm 1,011)$ \\
\hline & 3'A/wt & Yes & 151 & $+60( \pm 462)$ & 143 & $-7.495( \pm 142.232)$ & $-0,140( \pm 1,488)$ \\
\hline & 3'A/3'A & No & 08 & $+23( \pm 94)$ & 08 & $-32.585( \pm 124.644)$ & $-1,498( \pm 1,390)$ \\
\hline & $3^{\prime} \mathrm{A} / 3^{\prime} \mathrm{A}$ & Yes & 23 & $-6( \pm 98)$ & 21 & $+14.240( \pm 34.849)$ & $+0,021( \pm 0,567)$ \\
\hline
\end{tabular}

${ }^{a}$ Group 1: ASYMP, HIV-1-infected asymptomatic patients with $\mathrm{CD} 4^{+} \mathrm{T}$ cell counts $\geq 350$ cells $/ \mathrm{mm}^{3}$; group 2: SYMPT, HIV-1-infected patients with the symptoms of the disease and/or $\mathrm{CD}^{+} \mathrm{T}$ cell counts $<350 \mathrm{cells} / \mathrm{mm}^{3} .{ }^{\mathrm{b}} \mathrm{wt} / \mathrm{wt}$, wild-type/wild-type genotype; $3^{\prime} \mathrm{A} / \mathrm{wt}$, heterozygous mutation; $3^{\prime} / \mathrm{A} / 3^{\prime} \mathrm{A}$, homozygous mutation. ${ }^{\mathrm{c} A N O V A}, \mathrm{p}=0.058$. ${ }^{\mathrm{d} A N O V A}, \mathrm{p}=0.3679$. ${ }^{\mathrm{A}} \mathrm{ANOVA}, \mathrm{p}<0.001$ : antiretroviral therapy $\mathrm{p}=0.0203$. ARV, antiretroviral therapy; SD, standard deviation; $\mathrm{n}$, number of patients.

SYMPT patients. The values observed for the patients with the SDF1-3'A/3'A genotype who both had initiated and had not initiated ARV was lower than that observed in the patients with the SDF1-wt/wt genotype. Among the patients with the SDF1-wt/wt genotype who had not initiated ARV, the median was 87,000 copies/ml (range $<400-751,000$, IQR 17,200-278,000) and among those who had initiated ARV, the median was 811 copies/ml (range $<400-751,000$, IQR $<400$ 17,000). Among the patients with the SDF1-3'A/3'A genotype who had not initiated ARV, the median was 20,780 copies/ml (range 2560-56,800) and among the patients who had initiated ARV, the median was $<400$ (range $<400-395,000$, IQR $<400-4,970$ ). However, these differences were also not statistically significant ( $\mathrm{p}=0.1431$ and 0.5535 , respectively).

SDF1/CXCL12 genetic polymorphism and the clinical course of HIV-1-infection. The ASYMPT and SYMPT patients were followed for a median period of 29.3 months $(<1-39.3$ months) and for a median period of 29.2 months $(<1-39.3$ months), respectively, a difference not statistically significant ( $\mathrm{p}=0.567$ ). The time from the first HIV-1-positive test for the ASYMPT patients was shorter than those for the SYMPT patients $(\mathrm{p}=0.0003)$.

Tables II and III show the clinical course of the ASYMPT and SYMPT patients, respectively. Regarding the 161 ASYMPT patients, information was not obtained for 4 (2.5\%), $115(71.4 \%)$ remained asymptomatic, and $42(26.1 \%)$ progressed to AIDS. Of these, all of the 7 patients homozygous for the SDF1-3'A variant remained asymptomatic $(\mathrm{p}=0.1906)$, even though six of them had not initiated ARV. Among the 617 SYMPT patients with AIDS, information was not obtained for $6(1.0 \%)$ patients and $40(6.5 \%)$ progressed to death. Of these, $6 / 196(3.1 \%)$ heterozygous patients, and 1/33 (3.0\%) homo-zygous patients for the SDF1-3'A allele progressed to death $(\mathrm{p}=0.029)$.

SDF1/CXCL12 genetic polymorphism and laboratory markers of the course of HIV-1 infection. A mean of 4.4 $\mathrm{CD}^{+}{ }^{+} \mathrm{T}$ cell counts (range 1-9) and 4.9 viral load determinations (range 1-9) were performed for each patient enrolled in the study. Considering that at least two evaluations were required to calculate the slopes of the $\mathrm{CD}^{+}{ }^{+} \mathrm{T}$ cell counts and of plasma HIV-1 RNA levels, we gathered sufficient data from 133 ASYMPT and 575 SYMPT patients to estimate the $\mathrm{CD}^{+} \mathrm{T}$ cell slopes and from 110 ASYMPT and 531 SYMPT patients to estimate the viral load slope. Of these, $80.3 \%$ were submitted to at least three $\mathrm{CD}^{+} \mathrm{T}$ cell counts, and $68.6 \%$ to at least four $\mathrm{CD}^{+}{ }^{+} \mathrm{T}$ cell counts. For the viral load measurements, $67.9 \%$ were submitted to at least three measurements, and $59.9 \%$ to at least four viral load measurements.

As shown in Table IV, the immunological response, evaluated by the CD4 ${ }^{+} \mathrm{T}$ cell counts, of the ASYMPT and SYMPT patients was heterogeneous. After the analyses were adjusted for ARV and for the overall association of SDF1 genotypes with the $\mathrm{CD} 4^{+} \mathrm{T}$ cell counts and with the plasma HIV-1 RNA levels (expressed as copies/ml), the changes per year observed during the follow-up period were not significant $(\mathrm{p}=0.058$ and $\mathrm{p}=0.3679$, respectively). When the viral load was 
expressed as $\log _{10}$ copies/ml, the differences observed during the follow-up period were significant $(\mathrm{p}<0.0001)$. However, these differences could be attributed to the effect of ARV. The patients who had not initiated ARV showed a lower reduction of the number of HIV-1 RNA $\log _{10}$ copies/ml than the patients who had initiated the therapy $(\mathrm{p}=0.0203)$.

\section{Discussion}

This is the first sample survey undertaken to determine the effect of SDF1/CXCL12 genetic polymorphism on the clinical course of HIV-1 infection among Brazilian patients infected with HIV-1. The demographic, immunological and virological characteristics of the patients enrolled in this study were described previously (29) and are consistent with the data reported by the Brazilian Ministry of Health (24) and by other investigators regarding the major features of the HIV/AIDS epidemic in Brazil (30), i.e., the steady decrease in the male to female ratio as a result of an increasing proportion of female patients fueled by heterosexual transmission; and the increased number of HIV/AIDS cases among both younger and older individuals. The predominance of SYMPT patients among those infected with HIV-1 enrolled in the study may reflect a delay in HIV-1 diagnosis and in the access to specialized sexually transmitted disease centers for this population. It may also indicate that this is a population with more time exposure to the risk factors associated with HIV-1 infection.

The higher viral loads observed in the SYMPT patients compared to the ASYMPT HIV-1-infected patients substantiated the theory that the higher a person's viral load, the greater the risk of disease progression or death (31). The effectiveness of ARV was demonstrated by the lower viral load of SYMPT patients, which had an impact on the restoration of their immune response and their life expectancy, as also reported by others $(32,33)$.

The frequencies of homozygosity of the SDF1-3'A and the SDF1-3'A alleles among the ASYMPT and SYMPT HIV-1infected patients can be explained by the heterogeneous ethnic structure of the Brazilian population (34), were consistent with data reported for other populations, and also confirmed the global distribution of the SDF1/CXCL12 polymorphism reported among the different populations assessed $(15,21,22)$.

To examine the role of SDF1/CXCL12 polymorphism in the clinical course of HIV-1 infection, we did not use the Kaplan-Meier and Cox proportional hazard analysis for three reasons; first, the short follow-up period evaluated in this longitudinal study; second, the limited number of patients who carried the SDF1-3'A/3'A genotype in the ASYMPT and SYMPT groups; and third, the time of infection and seroconversion was unknown in the majority of the HIV-1-infected patients. The identification of the time of infection could not be determined in this study and may have shown significance with regards to SDF1-3'A mutation and disease progression. This is a weakness which is difficult to overcome (even with surrogate markers, as attempted) without longitudinal screening of a seronegative population.

Although the majority of the SDF1-3'A homozygous ASYMPT patients showed evidence of slow progression to AIDS, the limited number of ASYMPT patients with this genotype may have contributed to the nonsignificant results.
However, the results obtained in the present longitudinal study of HIV-1-infected ASYMPT patients agree with previous studies showing that association with the SDF1-3'A homozygous mutation did not influence the clinical course of asymptomatic patients $(13,14,18,19)$. Actually, some studies have associated SDF1-3'A homozygosity with a faster decay of $\mathrm{CD}^{+} \mathrm{T}$ cells and progression to AIDS $(11,12,17)$. In another study the effects of CCR2 and SDF1/CXCL12 were observed only among wild-type CCR5 homozygotes, suggesting that these effects are masked by the predominant role of the CCR5- $\Delta 32$ mutant (35).

Examining the lower number of deaths during the followup period that occurred among the SYMPT patients with the heterozygous and homozygous SDF1-3'A allele, it appears that there is no difference in mortality rate between these groups. However, there was a significant difference between the wild-type patients, suggesting that both homozygous and heterozygous genotypes could have a possible late-stage protective effect on the clinical outcome of HIV-1 patients after the AIDS diagnosis. This result agrees, in part, with previously reported data showing that homozygosity for the SDF1-3'A mutation is associated with an accelerated progression to AIDS but also with a subsequent prolonged survival after AIDS diagnosis (12). The observations that the effect of the SDF1-3'A mutation could be more protective in later stages of AIDS than in earlier stages is consistent with the fact that HIV-1 primarily uses a single receptor, CCR5, in the early stages of infection and expands its co-receptor use to include CCR5, CCR2B, CCR3, and CXCR4 in patients with disease progression (36).

Although the present study evaluated a very limited number of subjects who were homozygous for the allele of interest, the absence of other important confounder variables, such as the race of the patients, the access to care, and the route of HIV-1 infection, could have contributed to reducing this weakness. First, the frequency of SDF1/CXCL12 genotypes did not vary significantly with the race of the population evaluated in this study as mentioned previously (23); second, all the individuals enrolled had similar access to medical care including ARV therapy and prophylaxis for opportunistic infections, despite differences in socioeconomic level; and third, along the same lines it would be important to relate that the distribution of patients in various HIV-1 risk categories could not influence the results obtained in the follow-up. Considering the lower number of intravenous drug users compared with the heterosexual route of HIV-1 related by most of the patients included in this cohort, and reported elsewhere (29), the risk of other infections that share the blood route of HIV-1 infection may not be a factor that could influence risk of death of the patients evaluated.

The SDF1/CXCL12 genetic polymorphism showed no evidence of association with baseline $\mathrm{CD}^{+}$and $\mathrm{CD}^{+}{ }^{+} \mathrm{T}$ cell counts or with the plasma HIV-1 RNA levels observed in ASYMPT or SYMPT patients, independent of the ARV. These results are consistent with those observed by some authors $(15,34)$ but contradict those reported in other studies that showed an association of SDF1/CXCL12 genotypes with low $\mathrm{CD}^{+} \mathrm{T}$ cell count and low viral activity (37). However, the results showing higher plasma HIV-1 RNA levels in the patients homozygous for SDF1 wild-type genotype than 
those observed in the patients with other SDF1/CXCL12 genotypes are consistent with the results obtained in a metaanalysis study (18) in which seroconverter HIV-1 patients with SDF1-3'A homozygosity showed lower plasma HIV1 RNA levels, with a difference of $-0.20 \log _{10}$ copies $/ \mathrm{ml}$, although this difference was nonsignificant. The higher $\mathrm{CD}^{+} \mathrm{T}$ cell counts and lower plasma HIV-1 RNA levels observed in SDF1-3'A homozygotes who did not initiate ARV are also consistent with the hypothesis that the SDF13'A mutation involves up-regulation of the quantity of SDF1 protein available to bind CXCR4 and to stem the viral replication of late-stage T-tropic HIV-1 strains in infected patients (10).

The SDF1/CXCL12 genetic polymorphism did not affect the surrogate markers of HIV-1 disease progression such as $\mathrm{CD}^{+} \mathrm{T}$ cell decline and plasma HIV-1 RNA levels in this follow-up study. The wide variability observed in these markers is consistent with previous studies (33) and the changes in the $\mathrm{CD} 4^{+} \mathrm{T}$ cell counts and in the viral load depend on some host factors such as age and genetic polymorphisms (33). The integrity of the immune system, the ARV schedules, the compliance with the therapeutic regimen, the presence of the reactivation of chronic infections in HIV-1-infected patients could also influence the changes in $\mathrm{CD}^{+} \mathrm{T}$ cell counts and the suppression of viral replication, and the presence of the SDF13'A allele may not be sufficient, by itself, to restore the $\mathrm{CD}^{+}$ $\mathrm{T}$ cell repertoire.

However, the results obtained for the HIV-1-infected patients evaluated in this study underscore the importance of continuing the investigation of new therapeutic strategies to block CXCR4 co-receptor binding (38-40). HIV-1-infected patients in the advanced stages of the disease and/or with multiresistance to the antiretroviral agents currently available could benefit from these new antiretroviral agents.

Because there are conflicting data regarding the role of the SDF1/CXCL12 homozygous genotype, further studies with a longer follow-up period and with the enrollment of a larger sample of patients are needed to determine whether the SDF13'A mutation is involved in the clinical and laboratory outcomes of HIV-1-infection in this population. Moreover, additional genetic polymorphisms including CCR5- $\Delta 32$, and CCR2-64I, have been evaluated in this cohort of patients in order to show a more comprehensive picture of the influence of host genetics on HIV-1 disease progression in Brazilian populations. More genetic studies may identify a possible genotype or genotype association that could serve as a marker of disease progression in this population. The genetic marker would be useful to better characterize the genetic epidemiology of HIV-1 infection and to detect individuals at a high risk for a faster disease progression, guaranteeing the use of different or more aggressive therapeutic strategies or monitoring over a shorter period of time, or both.

\section{Acknowledgments}

We thank the Health Ministry-Brazilian National Sexually Transmitted Disease/AIDS program (CN-DST/AIDS) for their financial support with the cooperative agreement of the State University of Londrina (Grants UNESCO-UEL CFA 667/01), the Londrina University Hospital for technical and administrative support, and the PIBIC-CNPq program for student grants.

\section{References}

1. Fauci AS, Pantaleo G, Stanley $S$ and Weissman D: Immunopathogenic mechanisms of HIV infection. Ann Intern Med 124: 654-663, 1996

2. Alkhatib G, Combadiere C, Broder CC, et al: CC CKR5: a RANTES, MIP-1 $\alpha$, MIP-1ß receptor as a fusion cofactor for macrophage-tropic HIV-1. Science 272: 1955-1958, 1996.

3. Berson JF, Long D, Doranz BJ, Rucker J, Jirik F and Doms RW: A seven-transmembrane domain receptor involved in fusion and entry of T-cell-tropic human immunodeficiency virus type 1 strains. J Virol 70: 6288-6295, 1996.

4. Choe H, Farzan M, Sun Y, et al: The beta-chemokine receptors CCR3 and CCR5 facilitate infection by primary HIV-1 isolates. Cell 85: 135-148, 1996.

5. Doranz BJ, Grovit-Ferbas K, Sharron MP, et al: A dual-tropic primary HIV-1 isolate that uses fusin and the beta-chemokine receptors CKR-5, CKR-3, and CKR-2b as fusin cofactors. Cell 85: 1149-1158, 1996.

6. Dragic T, Litwin V, Allaway GP, et al: HIV-1 entry into CD4+ cells is mediated by the chemokine receptor CC-CKR-5. Nature 381: 667-673, 1996

7. Feng Y, Broder CC, Kennedy PE and Berger EA: HIV-1 entry cofactor: functional cDNA cloning for a seven-transmembrane, $\mathrm{G}$ protein-coupled receptor. Science 272: 872-877, 1996.

8. Liao F, Alkahatib G, Peden KWC, Sharma G, Berger EA and Farber JM: STRL33, a novel chemokine receptor-like protein, functions as a fusion cofactor for both macrophage-tropic and $\mathrm{T}$ cell-line tropic HIV-1. J Exp Med 185: 1-9, 1997.

9. Liao F, Lee H-H and Farber JM: Cloning of STRL22, a new human gene encoding a $\mathrm{G}$ protein-coupled receptor related to chemokine receptors and located on chromosome $6 \mathrm{q} 27$. Genomics 40: 175-180, 1997.

10. Winkler C, Modi W, Smith MW et al: Genetic restriction of AIDS pathogenesis by an SDF-1 chemokine gene variant. Science 279: 389-393, 1998.

11. Mummidi S, Ahuja SS, Gonzalez E, et al: Genealogy of the CCR5 locus and chemokine system gene variants associated with altered rate of HIV-1 disease progression. Nat Med 4: 786-793, 1998.

12. van Rij RP, Broersen S, Goudsmit J, Coutinho RA and Schuitemaker H: The role of a stromal cell-derived factor- 1 chemokine gene variant in the clinical course of HIV-1infection. AIDS 12: F85-F90, 1998.

13. Easterbrook PJ, Rostron T, Ives N, Troop M, Gazzard BG and Rowland-Jones SL: Chemokine receptor polymorphisms and human immunodeficiency virus disease progression. J Infect Dis 180: 1096-1105, 1999.

14. Magierowska M, Theodorou I, Debré P, et al: Combined genotypes of CCR5, CCR2, SDF1, and HLA genes can predict the long-term nonprogressor status in human immunodeficiency virus-1-infected individuals. Blood 93: 936-941, 1999.

15. Rousset D, Soares J-L, Reynes J-M, Caruz A, Flye Sainte Marie F and Virelizier J-L: High frequency of the 3'A mutation of the SDF-1 gene in Cambodia. AIDS 13: 420, 1999.

16. Shieh B, Liau Y-E, Yan Y-P, et al: Alleles that may influence HIV-1 pathogenesis in Chinese subjects. AIDS 13: 421, 1999.

17. Brambilla A, Villa C, Rizzardi G, et al: Shorter survival of SDF1-3'A homozygotes linked to $\mathrm{CD}^{+}{ }^{+} \mathrm{T}$ cell decrease in advanced human immunodeficiency virus type 1 infection. J Infect Dis 182: 311-315, 2000.

18. Ioannidis JPA, Rosenberg PS, Goedert JJ, et al: Effects of CCR5 [Delta]32, CCR2-64I, and SDF-1 3'A alleles on HIV-1 disease progression: an international meta-analysis of individual-patient data. Ann Intern Med 135: 782-795, 2001.

19. Soriano A, Martínez C, García F, et al: Plasma stromal cellderived factor (SDF)-1 levels, SDF1-3'A genotype, and expression of CXCR4 on T lymphocytes: their impact on resistance to human immunodeficiency virus type 1 infection and its progression. J Infect Dis 186: 922-931, 2002.

20. Wang F-S, Hong W-G, Cao Y, et al: Population survey of CCR5- $\triangle 32$, CCR m303, CCR2b 64I, and SDF1 3'A allele frequencies in indigenous Chinese healthy individuals, and in HIV-1-infected and HIV-1-unifected individuals in HIV-1 risk groups. J Acquir Immune Defic Syndr 32: 124-130, 2003. 
21. Su B, Chakraborty R, Jin L, Xiao J and Lu D: An HIV-resistant allele is exceptionally frequent in New Guinean Highlanders. JAMA 280: 1830, 1998.

22. Su B, Jin L, Hu F, et al: Distribution of two HIV-1 resistant polymorphisms (SDF1-3'A and CCR2-64I) in East Asia and world populations and its implication in AIDS epidemiology. Am J Hum Genet 65: 1047-1053, 1999.

23. Reiche EMV, Watanabe MAE, Bonametti AM, Morimoto HK, Morimoto AA, Wiechmann SL, Matsuo T, Miranda HC, Reiche FV and Oliveira KB: Stromal cell-derived factor 1 (SDF1) genetic polymorphism in a sample of healthy individuals, seronegative individuals exposed to human immunodeficiency virus type 1 (HIV-1), and patients infected with HIV-1 from Brazilian population. Int J Immunogen 33: 127-133, 2006.

24. Brazil. Ministry of Health. Boletim Epidemiológico de AIDS. Vol. XVII, n.1, 01 à 52 semanas epidemiológicas, January December, 2003. Brazil. Ministry of Health. (in Portuguese)

25. Brazil. Ministry of Health. National Coordination of Sexually Transmitted Diseases (STD) and AIDS. Revisão da Definição Nacional de Caso de AIDS em indivíduos com 13 anos ou mais, para fins de Vigilância Epidemiológica. Brazil. Ministry of Health, Janeiro, 1998. (in Portuguese)

26. Brazil. Ministry of Health. Agência Nacional de Vigilância Sanitária (ANVISA). Portaria no. 488, June 17, 1998. (in Portuguese)

27. Dean AG, Dean JA, Coulombier D, et al: Epi Info, Version 6: a word-processing database, and statistics program for Public Health on IBM-compatible microcomputers. Centers for Disease Control and Prevention. Atlanta, GA, 1995.

28. SAS Institute Inc: SAS/STAT User's Guide, Version 6, Fourth Edition, Cary, NC: SAS Institute Inc, 1989.

29. Reiche EVM, Bonametti AM, Watanabe MAE, et al: Sociodemographic and epidemiological characteristics associated with human immunodeficiency virus type 1 (HIV-1) infection in HIV-1-exposed but uninfected individuals, and in HIV-1-infected patients from a southern Brazilian population. Rev Inst Med Trop S Paulo 47: 239-246, 2005.
30. Fonseca MGP, Szwarcwald CL and Bastos FI: Análise sociodemográfica da epidemia de Aids no Brasil, 1989-1997. Rev Saúde Pública 36: 678-685, 2002.

31. Mellors JW, Munoz A, Giorgi JV, et al: Plasma viral load and $\mathrm{CD}^{+}$lymphocytes as prognostic markers of HIV-1-infection. Ann Inter Med 126: 946-954, 1997.

32. Bartlett, G.G. and Gallant, J.E: Medical management of HIV infection Johns Hopkins Schools of Medicine, Baltimore, MD, pp1-38, 2003.

33. Yamashita TE, Phair JP, Muñoz A, et al: Immunologic and virologic response to highly active anti-retroviral therapy in the Multicenter AIDS Cohort Study. AIDS 15: 735-746, 2001.

34. Alves-Silva J, Santos MS, Guimarães PEM, et al: The ancestry of Brazilian mtDNA lineages. Am J Hum Genet 67: 444-461, 2000.

35. Hendel H, Hénon N, Lebuanec H, et al: Distinctive effects of CCR5, CCR2, and SDF1 genetic polymorphisms in AIDS progression. J Acquir Immune Defic Syndr 19: 381-386, 1998.

36. Connor RI, Sheridan KE, Ceradini D, Choe S and Landau NR: Change in coreceptor use correlates with disease progression in HIV-1-infected individuals. J Exp Med 185: 621-628, 1997.

37. Balotta C, Bagnarelli $\mathrm{P}$, Corvasce $\mathrm{S}$, et al: Identification of two distinct subsets of long-term nonprogressors with divergent viral activity by stromal-derived factor 1 chemokine gene polymorphism analysis. J Infect Dis 180: 285-289, 1999.

38. Fujii N, Nakashima $\mathrm{H}$ and Tamamura H: The therapeutic potential of CXCR4 antagonists in the treatment of HIV. Expert Opin Investig Drugs 12: 185-195, 2003.

39. Murakami T, Nakajima T, Koyanagi Y, et al: A small molecule CXCR4 inhibitor that blocks T Cell Line-tropic HIV-1infection. J Exp Med 186: 1389-1393, 1997.

40. Shepherd JC and Quinn TC: Entry inhibitors: a primer on the class and on its most promising agents. The Hopkins HIV Report 16: 1-11, 2004. 